\title{
CONCURRENT UNILATERAL CHROMATID DAMAGE AND DNA STRAND BREAKAGE IN RESPONSE TO 6- THIOGUANINE TREATMENT
}

\author{
Craig R. Fairchild ${ }^{*}+$ Jonathan Maybaum $\ddagger$ and Katherine A. Kennedy* $§$ \\ ${ }^{*}$ Department of Pharmacology. The George Washington University, Washington, DC 20037; and \\ tDepartment of Pharmacology, Upjohn Center for Clinical Pharmacology, University of Michigan \\ Medical School, Ann Arbor, MI 48109, U.S.A.
}

(Received 5 August 1985; accepted 24 February 1986)

\begin{abstract}
The delayed cytotoxicity of 6-thioguanine (TG) may relate to the arrest of cells in $G_{2}$ upon completion of one cell cycle after drug exposure. In Chinese hamster ovary ( $\mathrm{CHO}$ ) cells, both the unilateral chromatid damage in $\mathrm{G}_{2}$ chromosomes, determined by induction of premature condensed chromosome condensation [Maybaum and Mandel, Cancer Res. 43, 3852 (1983)], and incorporation of TG into DNA resulting in DNA strand breakage [Christic et al., Cancer Res. 44, 3665 (1984)] were correlated with cytotoxicity. We have studied the correlation between strand breakage and unilateral chromatid damage in L1210 cells. DNA breaks were detected only when cells were treated with TG $(0.25 \mu \mathrm{M})$ for one cell cycle time ( $12 \mathrm{hr})$ followed by $12 \mathrm{hr}$ in drug-free medium containing [ $\left.{ }^{3} \mathrm{H}\right]$ thymidine (TdR) to label the DNA. After simultaneous incubation of cells with drug and label during the first or second 12 -hr period, strand breaks were not found. Strand breaks increased with dose, which correlated with greater cytotoxicity $(0.01$ to $0.25 \mu \mathrm{M})$. Treatment of cells with $0.25 \mu \mathrm{M}$ TG for $12 \mathrm{hr}$, and transfer to drug-free medium for $12 \mathrm{hr}$ prior to making prematurely condensed chromosomes (PCC), resulted in unilateral chromatid damage. Prominent curving of $\mathrm{G}_{2}$ chromosomes with gapping and diffuse staining of one of the sister chromatids occurred. The 4-fold increase in the percentage of cells in $\mathrm{G}_{2}$ compared with control cells suggested $G_{2}$ arrest. When cells were treated with TG for $12 \mathrm{hr}$ and PCC made immediately, neither the arrest of cells in $G_{2}$ nor unilateral chromatid damage was observed. These data suggest that strand breaks and unilateral chromatid damage occur in the second cell cycle after TG exposure and that this damage may be important in TG-delayed cytotoxicity.
\end{abstract}

The antimetabolite, 6-thioguanine (TG), must be anabolized to thioguanylate to have activity as an antitumor agent [1]. TG, once activated, can alter cellular biochemistry at several sites. For example, TG depresses de novo purine synthesis through inhibition of purine ring formation or purine interconversion [2-4]. These effects on purine metabolism, however, have not always correlated with growth inhibition or cytotoxicity [5]. TG has also been found to replace guanine residues in both RNA and DNA $[6,7]$. Although RNA synthesis may be a target for TG activity $[8,9]$, TG incorporation into DNA and the subsequent effects of its incorporation on DNA structure and function have been the focus of many investigations [7,10-13]. TG is incorporated into DNA in a dose-dependent manner, and the extent of TG incorporation was correlated with cytotoxicity [7]. Although TG incorporation into DNA is probably a key event in the production of cytotoxicity, other events must occur before TG-induced toxicity is observed. Several investigators have found that mid to late $S$ phase cells exposed to TG complete DNA synthesis and progress through $\mathrm{G}_{2}$ into mitosis $[11,14]$. After cell division, the drug-treated cells

- Present address: Clinical Pharmacology Branch, Division of Cancer Treatment, National Cancer Institute, Bethesda, MD 20892.

$\S$ To whom requests for reprints should be addressed; recipient of Young Investigator Award, Eli Lilly Co. continue through a second $\mathrm{S}$ phase and subsequently become arrested in $\mathrm{G}_{2}$. Thus, it appears that arrest in $\mathrm{G}_{2}$ is associated with the delayed lethality induced by TG [11].

Antitumor drugs which cause $\mathrm{G}_{2}$ arrest have been shown to damage chromatin [15]. TG treatment has also been shown to alter chromatin structure $[12,16]$ and cause DNA strands breaks [7]. The damage to $\mathrm{G}_{2}$ chromatids as visualized by premature chromosome condensation consisted of curving and kinking of Chinese hamster ovary $(\mathrm{CHO})$ cell $\mathrm{G}_{2}$ prematurely condensed chromosomes (PCC) and unilateral gaps and diffuse staining $[12,16]$. The physical damage to the chromatin was dose dependent and correlated with the delayed cytotoxicity [12]. Cytotoxicity has also been associated with $\mathrm{TG}$ incorporation into DNA and subsequent production of single-strand breaks in $\mathrm{CHO}$ cells [7].

In the studies with $\mathrm{L} 1210$ cells reported here, DNA breakage, as detected by alkaline elution methods, and chromatin damage, as assessed by PCC analysis, have been correlated with drug-induced cytotoxicity. These studies suggest that the unilateral chromatid damage found after TG treatment may be a more general phenomenon and not restricted to a single cell type. Furthermore, these data support the hypothesis that $\mathrm{TG}$-induced toxicity requires cell progression and a second period of DNA replication after the incorporation of the drug into the DNA This second period of DNA synthesis results in 
chromatin damage and DNA strand breakage which are correlated with cytotoxicity.

\section{MATERIALS AND METHODS}

Drugs and chemicals. TG was dissolved in doubledistilled $\mathrm{H}_{2} \mathrm{O}$, and the concentration was determined by measuring the absorption at $321 \mathrm{~nm}$. $\left[{ }^{3} \mathrm{H}\right]$ Thymidine $(\mathrm{TdR})(80 \mathrm{Ci} / \mathrm{mmole})$ and $\left[{ }^{14} \mathrm{C}\right] \mathrm{TdR}$ (56 $\mathrm{mCi} / \mathrm{mmole}$ ) were obtained from RPI (Mount Prospect, IL) and Moravek Biochemicals, Inc. (Brea, CA) respectively. Ultraviolet-irradiated Sendai virus was provided by Dr. Walter Hittelman, Department of Developmental Therapeutics, the University of Texas System Cancer Center, M.D. Anderson Hospital and Tumor Institute, Houston, TX. Colcemid. RPMI 1640, alpha-minimum essential medium (MEM), dialyzed horse serum and calf serum were obtained from GIBCO Laboratories (Grand Island, NY). Fetal calf serum was obtained from Biofluids, Inc. (Rockville, MD). Unless otherwise noted, all other chemicals were obtained from standard chemical sources and were of the highest purity available.

Cell culture. L1210 cells were maintained in continuous suspension culture in RPMI 1640 medium supplemented with $10 \%$ dialyzed horse serum, penicillin G (10 units/l) and streptomycin (100 mg/l). Cells were passaged twice weekly, and a doubling time of $12 \mathrm{hr}$ was found. CHO cells were grown in monolayer culture in alpha-MEM with $10 \%$ calf serum and $5 \%$ fetal calf serum. The doubling time for these cells was $12 \mathrm{hr}$. Both cell lines were maintained in a humidified atmosphere of $95 \%$ air and $5 \% \mathrm{CO}_{2}$ at $37^{\circ}$.

Colony forming assays. The viability of L 1210 cells after vehicle or drug treatment was assessed using the soft agar cloning method of Chu and Fischer [17]. Cells were treated with TG for $12 \mathrm{hr}$ and washed twice, then diluted to a known cell number in RPMI 1640 supplemented with $20 \%$ dialyzed horse serum and agar $(0.12 \%)$. For each drug concentration, a minimum of three different dilutions of cells were plated in triplicate and incubated for $10-$ 12 days in a humidified atmosphere of $95 \%$ air- $5 \%$ $\mathrm{CO}_{2}$ at $37^{\circ}$. Colonies were counted and expressed as a percentage of control non-drug-treated cells. Control colony forming efficiencies were typically between 80 and $90 \%$.

Premature chromosome condensation. Visualization of unilateral chromatid damage and disturbances of cell cycle progression were assessed by premature chromosome condensation as described by Hittelman and Rao [18]. L1210 cells were exposed to $\mathrm{TG}$ for $12 \mathrm{hr}$. The drug was removed and the cells were resuspended in drug-free medium for an additional $12 \mathrm{hr}$. after which time PCC were made. Another group of cells was exposed to TG for $12 \mathrm{hr}$ and PCC were made immediately. Control cells received no drug treatment. Three million control or TG-treated L1210 cells were combined with one million mitotic CHO cells in $5 \mathrm{mM}$ piperazine- $N-N^{\prime}$ bis(2-ethanesulfonic acid) (PIPES) buffer at $\mathrm{pH} 7.4$ and mixed thoroughly. Mitotic CHO cells were prepared by mitotic detachment of cells that had been treated with $0.05 \mathrm{\mu g} / \mathrm{ml}$ colcemid for $3 \mathrm{hr}$.
The L1210/mitotic CHO cell mixture was centrifuged and resuspended in $0.5 \mathrm{ml}$ of Hanks' balanced salt solution (HBSS; GIBCO, Grand Island, NY) containing approximately 4000 hemagglutinating units of Sendi virus per ml of HBSS and then placed in an ice water bath at $4^{\circ}$ for $15 \mathrm{~min}$. The virus-cell fusion mixture was transferred to a $37^{\circ}$ water bath for $45 \mathrm{~min}$ after the addition of $50 \mu \mathrm{l}$ of an HBSS solution containing $100 \mathrm{mM} \mathrm{MgCl} 2$ and $4 \mu \mathrm{g} / \mathrm{ml} \mathrm{col}$ cemid. The cells were swollen hypotonically by the addition of $7 \mathrm{ml}$ of $0.075 \mathrm{M} \mathrm{KCl}$ and incubated at room temperature for $12 \mathrm{~min}$. Cells were collected by centrifugation. fixed with methanol/glacial acetic acid (3:1), and then dropped onto clean, wet microscope slides. The air-dried slides were stained with $2 \%$ aceto-orcein (GIBCO). The slides were coded and then scored blindly using a light microscope. The spreads were located at $400 \times$ and then examined at $1000 \times$ to determine the PCC morphology. At least $100 \mathrm{PCC}$ spreads were scored for each treatment group.

Alkaline elution assay for single-strand breaks. Alkaline elution methods were used to assess DNA strand breaks according to the method described by Kohn et al. [19]. L1210 cells were labeled with $\left[{ }^{3} \mathrm{H}\right] \mathrm{TdR}(0.1 \mu \mathrm{Ci} / \mathrm{ml}, 1 \mu \mathrm{M})$ and treated with $\mathrm{TG}$ in one of four ways, as illustrated in Fig. 1, before analysis by alkaline elution methods. One group of cells (I) was simultaneously treated with $\left[{ }^{3} \mathrm{H}\right] \mathrm{TdR}$ and $0.25 \mu \mathrm{M}$ TG for $12 \mathrm{hr}$ and then incubated for an additional $12 \mathrm{hr}$ in fresh medium. Group II cells were treated in a similar fashion, except that alkaline elution analysis for single-strand breakage was performed immediately after TG exposure for $12 \mathrm{hr}$. A third group of cells (III) was prelabeled with $\left[{ }^{3} \mathrm{H}\right] \mathrm{TdR}$ for $12 \mathrm{hr}$. After labeling, the medium was removed and new medium containing $0.25 \mu \mathrm{M} \mathrm{TG}$ was added for $12 \mathrm{hr}$. Group IV cells were exposed to $0.25 \mu \mathrm{M}$ TG for $12 \mathrm{hr}$. After drug exposure, the medium was removed and replaced with drug-free medium containing $\left[{ }^{3} \mathrm{H}\right] \mathrm{TdR}$. Group IV cells were incubated for an additional 12 hr prior to analysis of DNA single-strand breaks by alkaline elution methods.

Control cells were labeled with $\left[{ }^{3} \mathrm{H}\right] \mathrm{TdR}$ or $\left[{ }^{14} \mathrm{C}\right] \mathrm{TdR}(0.01, \mu \mathrm{Ci} / \mathrm{ml}, 1 \mu \mathrm{M})$ for $12 \mathrm{hr}$. Control ${ }^{3} \mathrm{H}-$ labeled cells received either 0 or 300 rads of $\mathrm{X}$ irradiation on ice just prior to alkaline elution analysis. Internal standard cells (labeled with $\left[{ }^{14} \mathrm{C}\right] \mathrm{TdR}$ )

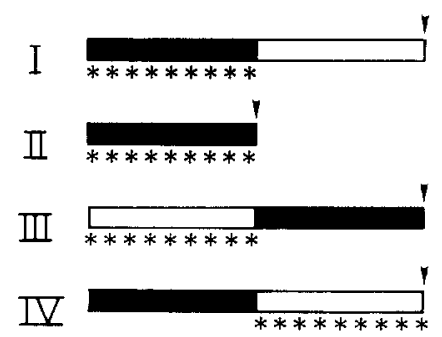

Fig. 1. Schedule of drug treatment and labeling used in alkaline elution experiments. Closed bars represent $12-\mathrm{hr}$ exposure to TG-containing medium, open bars indicate 12hr incubation in drug-free medium, asterisks indicate the presence of $\left[{ }^{3} H\right] T d R$, and arrows indicate the time at which cells were harvested for elution analvsis. 
received 300 rads of $\mathrm{X}$-irradiation on ice just prior to alkaline elution analysis. All cells were kept at $4^{\circ}$ in the dark until analyzed. Aliquots of experimental $\left({ }^{3} \mathrm{H}\right.$-labeled) cells and the internal standard $\left({ }^{1+} \mathrm{C}\right.$ labeled) cells were mixed and applied to $2 \mu \mathrm{m}$ polycarbonate filters (Nucleopore Corp., Pleasanton, CA). The cells were then lysed using a lysis buffer containing $5 \%$ sodium dodecyl sulfate, $20 \mathrm{mM}$ EDTA and $100 \mathrm{mM}$ glycine at $\mathrm{pH} 10$. This solution was drained by gravity, and $2 \mathrm{ml}$ of the lysis solution containing proteinase $\mathrm{K}(0.5 \mathrm{mg} / \mathrm{ml})$ was pumped through the filter at the rate of $2 \mathrm{ml} / \mathrm{hr}$ to remove protein associated with the DNA. The DNA was eluted with $40 \mathrm{ml}$ of solution containing $0.1 \mathrm{M}$ tetrapropyl ammonium hydroxide, $20 \mathrm{mM}$ EDTA, and $0.1 \%$ sodium dodecyl sulfate, $\mathrm{pH} 12.1$, at a rate of $2 \mathrm{ml} / \mathrm{hr}$. Fractions were coilected directly into miniscintillation vials at 90 -min intervals for $15 \mathrm{hr}$. Liquiscint (National Diagnostics, Somerville, NJ) counting solution containing $0.7 \%$ glacial acetic acid was added, and the fractions were counted on a Beckman LS 6800 liquid scintillation counter. The filters were collected, and the residual DNA was hydrolyzed with $0.4 \mathrm{ml}$ of $1 \mathrm{~N} \mathrm{HCl}$ for $1 \mathrm{hr}$ at $90^{\circ}$ to determine the amount of radioactivity remaining on the filter. Scintillation counting was carried out as described above. To remove any residual radioactivity from the pump tubing or system, $2 \mathrm{ml}$ of $1 \mathrm{~N} \mathrm{NaOH}$ was flushed through the system, collected as a single fraction, and counted.

To determine the total $\left[{ }^{3} \mathrm{H}\right]$ and $\left[{ }^{14} \mathrm{C}\right]$ contained in a sample, the amounts in the individual fractions were summed along with that contained in the lysis solution, the $\mathrm{NaOH}$ fraction, and the filter fraction. The fraction of $\left[{ }^{3} \mathrm{H}\right]$ (experimental cells) remaining on the filter was plotted against the fraction of $\left[{ }^{14} \mathrm{C}\right]$ (internal standard cells) remaining on the filter.

\section{RESULTS}

Cytotoxicity studies. L1210 cells exposed to increasing concentrations of TG for $12 \mathrm{hr}$ showed a dose-related decrease in survival as assessed by colony formation in soft agar (Fig. 2). The threshold for toxicity was $0.01 \mu \mathrm{M}$. At a concentration of $0.25 \mu \mathrm{M}$ TG, a $2 \log$ cell kill was found. Morphologic and biochemical analyses of TG-induced damage were conducted in cells exposed to $0.25 \mu \mathrm{M}$ drug.

Cell cycle position classified by PCC morphology. L1210 cells were treated with TG or vehicle and fused with mitotic $\mathrm{CHO}$ cells to make PCC as described in Materials and Methods. PCC spreads were scored as to their position in the cell cycle, based on chromatin morphology. The classification scheme relies on the observation that, as cells progress from $G_{1}$ into $S$, the chromatin decondenses in preparation for DNA synthesis in a characteristic manner [18]. Decondensation is manifested in two ways. First, chromatin structures elongate. Second, discontinuities are observed as apparent breaks or gaps in the chromatin. These discontinuities are not frank breaks in DNA structure, but represent areas in which DNA has become unwound to such an extent that it is no longer visible under the light microscope. As cells progress from $S$ into $G_{2}$, bifilial PCC are apparent $[18,20]$.

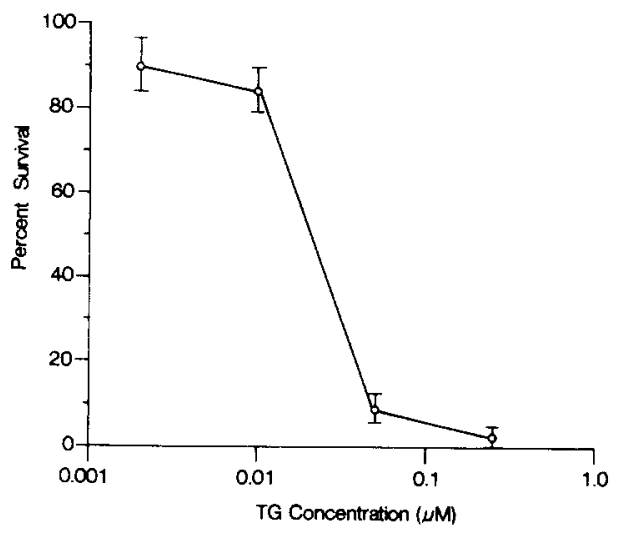

Fig. 2. L1210 cell survival after 12-hr exposure to TG. L1210 cells in logarithmic growth were exposed to TG $(0.0025$ to $0.25 \mu \mathrm{M})$ for $12 \mathrm{hr}$ and then prepared for colony forming assays as described in Materials and Methods. Data are expressed as a percentage of untreated control cells. Each point represents the mean $\pm S$.E. for at least three determinations.

The classification scheme consisted of four PCC groups in addition to the distinct bifilial $G_{2}$ PCC. Group 1 consists of PCC that are highly to moderately condensed single chromatid structures with few or no discontinuities and which arise from cells in early to mid $\mathrm{G}_{1}$ (see Fig. 3). In group 2 spreads, the chromatin is more extended than in group 1 and some areas of discontinuity are found. The chromatin is mostly discontinuous in group 3 , although some regions of extended chromatin still exist. Spreads classed as 2 and 3 arise from cells that are in late $G_{1}$ or early $\mathbf{S}$. In group 4 , the chromatin is maximally decondensed and completely discontinuous in appearance and arises from cells in S phase. PCC spreads which were completely or nearly completely bifilial were classified as $\mathrm{G}_{2}$. Spreads having this morphology come from cells that have finished replication and have initiated recondensation in preparation for mitosis [20]. These classifications are based upon the classical descriptions reported by Rao and Johnson [20] and further discussed by Rao et al. [21]. Although no other methods were used in the present study to correlate PCC morphology and cell cycle position, prior work in this field has demonstrated the usefulness of this technique in assessing cell cycle position after drug treatment $[12,18,20]$.

Classification of unilateral chromatid damage in vehicle or drug-treated cells. The distinctly bifilial $\mathrm{G}_{2}$ PCC spreads were further classified as to the degree of unilateral chromatid damage. This unique type of damage to chromatid structures after exposure to TG was described originally in $\mathrm{G}_{2}$ PCC of CHO cells [16]. This form of chromosomal disruption is distinct from the usual gaps, breaks and exchanges often observed with other DNA damaging agents $[22,23]$. Unilateral chromatid damage was observed as curling and kinking of $\mathrm{G}_{2}$ PCC. In addition, numerous regions which were diffusely stained or gapped were found in the kinked and curled chromatid. The sister chromatid, however, showed no evidence of damage. In the studies reported here in L1210 cells, we also 


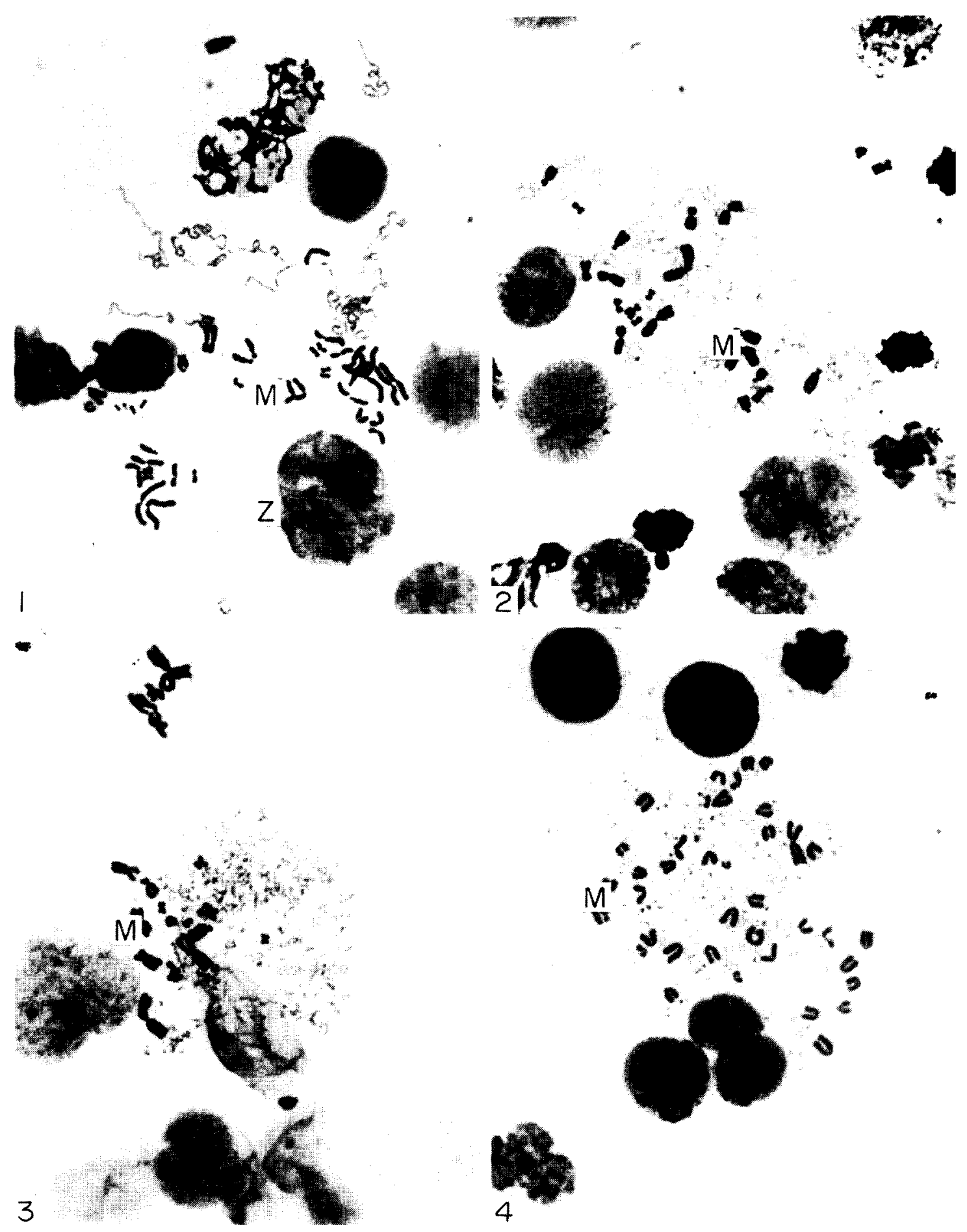

Fig. 3. Photomicrographs of PCC decondensation groups of L1210 cells. The spreads pictured here are representative of the degree of chromatin decondensation. which was the criterion used to assign a PCC spread to either group 1, 2. 3. or 4 . The characteristies of each group are discussed in Results. "M" indicates CHO cell mitotic chromosomes. An example of G. PCC spreads is found in Fig. 4. 


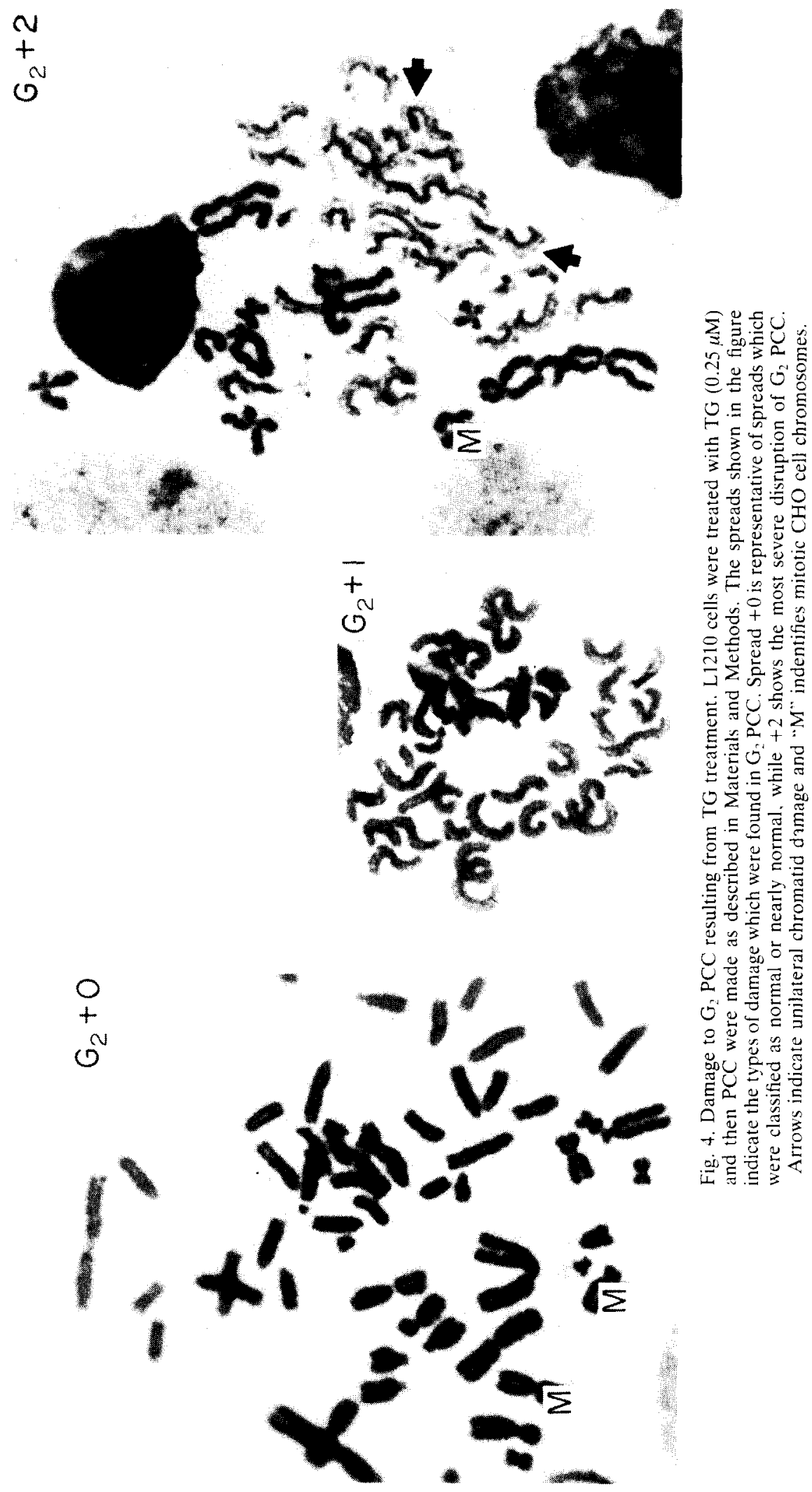


found unilateral chromatid damage in $G_{2}$ cells. This damage was classified according to the degree of deformation observed and assigned to one of three categories, $\mathrm{G}_{2^{-}}+0, \mathrm{G}_{2^{-}}+1$, or $\mathrm{G}_{2^{-}}+2$ (Fig. 4). Spreads that contained less than three kinks were assigned a deformation score of $\mathrm{G}_{2^{-}}+0$. In this scoring system, a "kink" was defined as a bend in the $G_{2}$ chromatid of at least $90^{\circ}$ which occurred over a distance of not more than twice the width of the PCC. A curved region of the chromatid that included the centromere was not classed as a kink. To be assigned a $\mathrm{G}_{2^{-}}+1$ deformation score, a spread had to contain PCC with at least three kinks. but no differential chromatid staining. When at least three kinks and regions of differential chromatid containing were present, the spread was assigned a deformation score of $\mathrm{G}_{2^{-}}+2$. If it was unclear as to which class a particular spread should be assigned, the lower of the two classifications was used. All slides were coded before the slides were scored for unilateral chromatid damage by an independent observer. After evaluation, the codes were broken and the accumulated data were assessed. In no manner does the scoring system used to classify the unilateral chromatid damage found in $G_{2}$ PCC imply any progression through the $G_{2}$ phase of the cell cycle.

Analysis of TG-treated cells by PCC decondensation morphology. To analyze cell cycle position after TG treatment, the decondensation morphologies of PCC were classified. Figure 5 shows PCC

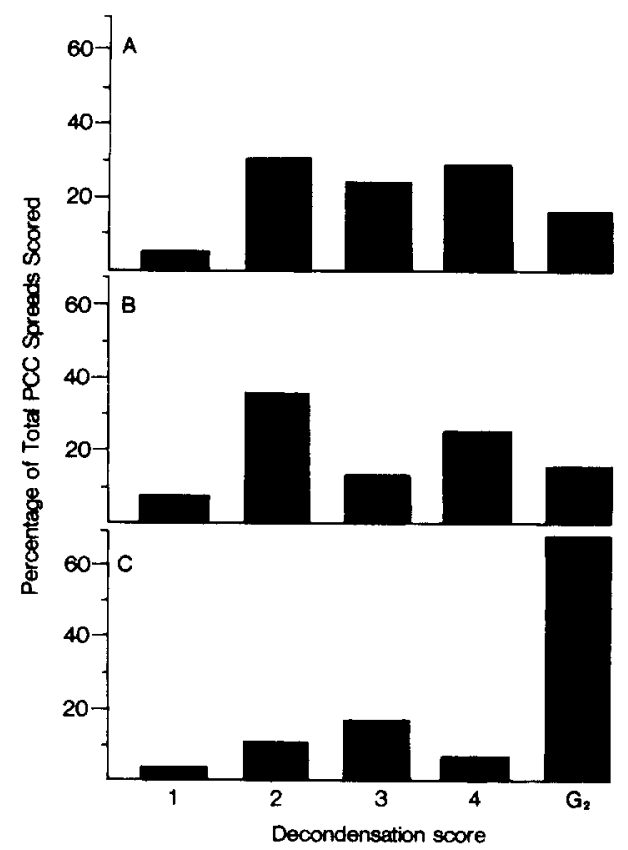

Fig. 5. Frequency distributions of PCC decondensation morphologies according to TG treatment schedule. Data are: treatment $\mathrm{A}$, control cells; treatment $\mathrm{B}$, exposure to TG $(0.25 \mu \mathrm{M})$ for $12 \mathrm{hr}$ followed by PCC analysis; treatment $\mathrm{C}$, same as B, but incubated for an additional $12 \mathrm{hr}$ in drugfree medium before $\mathrm{PCC}$ analysis. The results are expressed as a percentage of the total PCC spreads scored in each treatment group; $100-200$ spreads were scored for each group. decondensation histograms for three types of drug treatment: vehicle-treated control cells (treatment A), cells treated with TG $(0.25 \mu \mathrm{M})$ for $12 \mathrm{hr}$ and then analyzed by premature chromosome condensation (treatment $B$ ), or cells treated with TG $(0.25 \mu \mathrm{M})$ for $12 \mathrm{hr}$ followed by an additional $12 \mathrm{hr}$ in drug-free medium with subsequent $\mathrm{PCC}$ analysis (treatment C). Treatment $\mathrm{A}$ shows a typical distribution of PCC spreads for vehicle-treated control cells. As described above (Fig. 3), an increase in the numerical value of the decondensation score represents progression through the cell cycle from $\mathrm{G}_{1}$ into $\mathrm{S}$, with group 4 representing S-like PCC. For vehicle-treated cells, $80 \%$ of the total spreads scored were found in groups 2, 3 or $4 . \mathrm{G}_{2}$ spreads made up $15 \%$ of the total number scored. With treatment B (12-hr TG treatment and then immediate PCC analysis), the distribution of spreads was similar to that observed in control cells. Although about half as many group 3 spreads were found in treatment $B$ compared to treatment $\mathrm{A}$, approximately $80 \%$ of the spreads were classified as belonging in groups 2-4 and spreads in $\mathrm{G}_{2}$ made up about $15 \%$ of the scored spreads. In contrast, treatment $\mathrm{C}$ (12-hr $\mathrm{TG}$ exposure, followed by $12 \mathrm{hr}$ in TG-free medium. then PCC analysis) produced a PCC distribution that was very different from $A$ or $B . G_{2}$ spreads constituted $67 \%$ of the total spreads scored with a corresponding decrease in the number of spreads in groups 1 through 4 compared with control. The group 4 spreads represent those cells in $S$ phase. The percent of total spreads classified as in group 4 were equivalent for treatments $\mathrm{A}$ and $\mathrm{B}(22 \%)$. In contrast, for treatment $\mathrm{C}, 8 \%$ of the total spreads were classified as group 4 spreads.

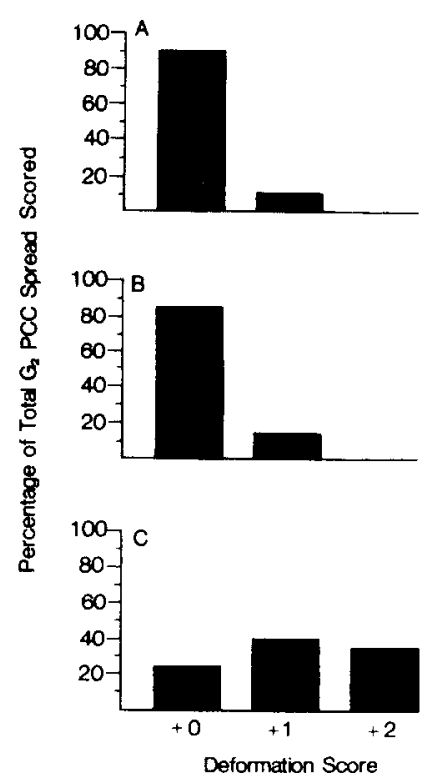

Fig. 6. Extent of $\mathrm{G}_{2}$ PCC damage according to TG treatment schedule. Treatments $A . B$, and $C$ were carried out as described in Fig. 5. The results are expressed as at percentage of the total number of $\mathrm{G}_{2} P C \mathrm{PC}$ spreads scored for each treatment group: $30-65 \mathrm{G}_{2}$ PCC spreads were examined for each group. 
Analysis of unilateral chromatid damage induced by $T G$. In addition, $\mathrm{G}_{2}$ spreads were further classified as to the extent of unilateral chromatid damage observed, as described above, and shown in Fig. 3. Ninety percent of the $\mathrm{G}_{2}$ PCC spreads from control cells appeared normal with virtually no kinking and were assigned a deformation score of +0 (treatment A in Fig. 6). A baseline level of moderate chromatid deformation $(+1)$ was observed in $10 \%$ of the control $\mathrm{G}_{2}$ spreads. Treatment $\mathrm{B}$ did not alter the distribution of unilateral chromatid damage in the $\mathrm{G}_{2}$ PCC. Treatment C, however, produced a major shift in the percentage of spreads with a higher deformation score. Nearly $80 \%$ of the $\mathrm{G}_{2}$ spreads scored had moderate to major unilateral chromatid damage with approximately equal numbers of $\mathrm{G}_{2}$ spreads in each category $(+1$ or +2 deformation scores). Only $20 \%$ of the $\mathrm{G}_{2}$ spreads analyzed in treatment $\mathrm{C}$ were
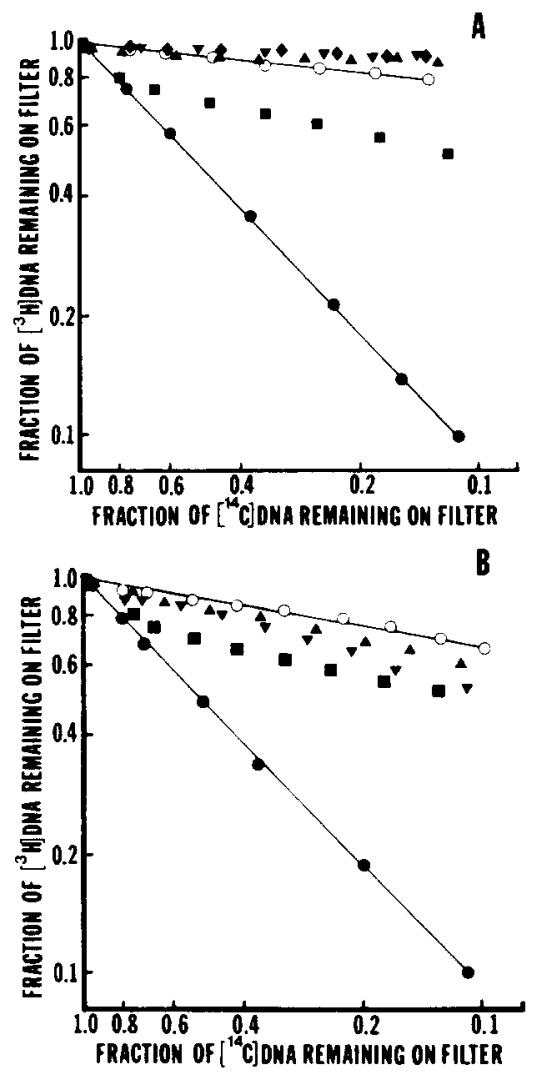

Fig. 7. DNA single-strand break production in L1210 cells according to TG schedule (A) and dose (B). Panel A, treatment schedules (see Fig. 1) were: I $(\boldsymbol{\Delta})$ simultaneous ${ }^{3} \mathrm{H}$-labeling and $\mathrm{TG}$ exposure for $12 \mathrm{hr}$ followed by $12 \mathrm{hr}$ in fresh medium; II ( $)$ simultaneous ${ }^{3} \mathrm{H}$-labeling and TG exposure for $12 \mathrm{hr}$; III ( $){ }^{3} \mathrm{H}$-prelabel for $12 \mathrm{hr}$ followed by 12-hr TG exposure without label; IV ( $)$ TG exposure for $12 \mathrm{hr}$ followed by $12 \mathrm{hr}{ }^{3} \mathrm{H}$-label. Ail TG treatments were with $0.25 \mu \mathrm{M}$ drug. In Panel $\mathrm{B}, \mathrm{L} 1210$ cells were treated with different doses of $T G$ according to schedule IV. TG doses were: $0.01 \mu \mathrm{M}(\boldsymbol{\Delta}), 0.025 \mu \mathrm{M}(\boldsymbol{\nabla})$, and $0.25 \mu \mathrm{M}(\mathbf{\square})$. In both panels $(O)$ represents control cells without treatment and (O) represents cells which received 300 rads of $X$-iradiation before alkaline elution. In all cases, ${ }^{14} \mathrm{C}$-labeled cells were given 300 rads of $\mathrm{X}$-irradiation prior to alkaline elution. found to exhibit normal $\mathrm{G}_{2}$ PCC morphology $(+0$ deformation score) with respect to kinking or differential chromatid staining.

Assessment of TG-induced strand breaks by alkaline elution. Alkaline elution was used to determine the ability of TG to cause breaks in the DNA of L1210 cells. Strand breaks were monitored after four different schedules of TdR labeling of DNA and TG treatment as described in Materials and Methods and illustrated in Fig. 1. Figure 7A shows that group IV produced the most rapid rate of elution, indicating that this labeling and treatment schedule produced DNA strand breaks. The single-strand break frequency in rad-equivalents for the experiment in Fig. $7 \mathrm{~A}$ was 113 . Cells treated according to schedules I, II, or III eluted from the filters at rates similar to that observed in non-drug-treated cells.

Because it appeared that TG treatment followed by $12 \mathrm{hr}$ post drug exposure labeling was the only schedule to result in strand breaks, a series of studies using this protocol was carried out to see if the strand break production was dose related. The results are shown in Fig. 7B. TG concentrations of $0.01,0.025$ and $0.25 \mu \mathrm{M}$ gave increasing amounts of strand break production, in which the single-strand break frequencies in rad-equivalents for the experiment shown in Fig. $7 \mathrm{~B}$ were 34,51 , or 101 respectively.

\section{DISCUSSION}

Both unilateral chromatid damage $[12,16]$ and DNA strand breakage $[7,13]$ have been proposed as mechanisms for cytotoxicity induced by TG. Other investigations have suggested that $T G$ toxicity is delayed $[11,12,14,16]$ with the appearance of chromatid damage in the cell cycle following TG incorporation $[11,12,16]$. Correlation of DNA strand breakage and/or chromatid damage with cytotoxicity has been difficult due to the use of different cell lines. The focus of this study was to correlate the production of unilateral chromatid damage and DNA strand breakage by TG in L1210 cells, which are sensitive to TG-induced toxicity. In addition, the studies reported here extend previous investigations which attempted to explain the mechanisms for delayed cytotoxicity of TG. L1210 cells incubated with 0.01 to $0.25 \mu \mathrm{M}$ TG for $12 \mathrm{hr}$ showed a doserelated increase in cytotoxicity. At the lower dose $(0.002 \mu \mathrm{M})$, no apparent cytotoxicity was found. The concentration of TG required to produce a $50 \%$ reduction in survival after a 12-hr exposure was estimated to be $0.02 \mu \mathrm{M}$. Increasing the exposure time for TG to $16 \mathrm{hr}$ lowered the $\mathrm{LC}_{50}$ to $0.008 \mu \mathrm{M}$ (data not shown). In CHO cells exposed to $\mathrm{TG}$ for $16 \mathrm{hr}, 0.5 \mu \mathrm{M}$ drug produces a $50 \%$ decrease in survival [12]. When a CHO cell subline, AA8, which was competent in DNA repair was studied, the reported $\mathrm{LC}_{50}$ was approximately $1 \mu \mathrm{M}$ after $24 \mathrm{hr}$ of exposure [7]. These results suggest that L1210 cells are 25 - to 125 -fold more sensitive to $\mathrm{TG}$ than $\mathrm{CHO}$ cells.

Because L1210 cells are more sensitive to TG, unilateral chromatid damage and DNA damage should occur at lower concentrations of TG, if these manifestations of nuclear disruption play an important role in TG lethality. Maybaum and Mandel 
$[12,16]$ demonstrated chromatid disruption in $\mathrm{CHO}$ ceils after the cells were exposed to TG. Two forms of chromatid disruption were observed by these investigators. At lower doses, $80 \%$ of the $\mathrm{G}_{2}$ PCC spreads exhibited prominent kinking $[12,16]$. At a higher dose $(4 \mu \mathrm{M})$, unilateral chromatid damage in the form of diffuse staining and gapping occurred in $20 \%$ of the $\mathrm{G}_{2}$ PCC spreads in addition to prominent kinking $\left(80 \%\right.$ of total $\mathrm{G}_{2}$ spreads) $[12,16]$. Furthermore, kinking was always observed in spreads which exhibited unilateral chromatid damage $[12,16]$. In the studies reported here, L1210 cells treated with $0.25 \mu \mathrm{M}$ TG exhibited extensive chromatin damage. Unilateral chromatid damage was found in $40 \%$ of the $\mathrm{G}_{2}$ PCC spreads (Fig. 6). The damage observed in L1210 cells (Fig. 6) was very similar to that seen in CHO cells $[12,16]$ : kinking in moderately damaged chromatin, while more severe disruption was manifest as kinking and unilateral chromatid damage. These data suggest that TGinduced toxicity is associated with the presence of unilateral chromatid damage and/or kinking in cell lines sensitive to TG. Furthermore, the unilateral chromatid damage induced by $\mathrm{TG}$ is not unique to CHO cells but may be a general feature of delayed TG toxicity

TG is known to incorporate into DNA, but this incorporation does not affect DNA synthesis immediately because TG-treated cells are able to complete $S$ phase and divide $[11,14]$. It is only after a second round of DNA synthesis that cell progression is disrupted, and the cells become arrested in $G_{2}$ [11]. The irreversible arrest in $G_{2}$ of TGtreated cells has been associated with a primary event leading to cell death. Data presented here and by Maybaum and Mandel $[12,16]$ suggest that the $G_{2}$ arrest of TG-treated cells may result from the disruption of chromatin structure which was manifested in these studies by kinking and unilateral chromatid damage. When L1210 cells were exposed to $0.25 \mu \mathrm{M}$ $\mathrm{TG}$ for $12 \mathrm{hr}$ and then PCC were made immediately (treatment B), no disruption of $\mathrm{G}_{2}$ PCC was seen (Fig. 6), nor was there arrest of cells in $\mathrm{G}_{2}$ (Fig. 5). When the cells were treated with $\mathrm{TG}$ for $12 \mathrm{hr}$ followed by a $12-\mathrm{hr}$ period in drug-free medium (treatment C), cells were arrested in $\mathrm{G}_{2}$ (Fig. 5) and chromatin disruption was observed in $\mathrm{G}_{2}$ PCC (Fig. 6). The doubling time for the L 1210 cells employed in the present report was $12 \mathrm{hr}$. Taken together the data suggest that at least two rounds of DNA synthesis must occur in order for TG-induced arrest in $\mathrm{G}_{2}$ and chromatin damage to be manifested in L1210 cells. In the present studies, the schedule which produced both $G_{2}$ arrest and chromatin damage was treatment $\mathrm{C}$. Treatment $\mathrm{C}$ permitted $\mathrm{TG}$ to be incorporated into DNA during the first $12 \mathrm{hr}$ of incubation, corresponding to one doubling time for L1210 cells. Other investigators have demonstrated that the incorporation of 2'-deoxy-6-thioguanosine5 -triphosphate into DNA proceeds efficiently when normal DNA is used as a template [24]. This first round of replication in $L 1210$ cells would lead to the presence of $T G$ in one strand of the DNA. After $12 \mathrm{hr}$ in drug-containing medium, the cells were washed and placed in fresh medium for an additional $12 \mathrm{hr}$ to permit a second round of DNA synthesis in the absence of TG. It is possible that during this second round of DNA synthesis, the TG-containing DNA strand acts as a faulty template and results in the production of kinked and/or unilaterally damaged chromatids. It is not known whether TG-containing DNA can be replicated in the normal manner. It has been shown, however, that the transcription of synthetic DNA substituted with TG is inhibited [25].

Chromatin damage induced by TG appears to occur in the newly synthesized DNA that does not necessarily contain TG, but which is replicated from the TG-containing DNA strand. This is demonstrated by the appearance of strand breaks only when DNA is labeled during the second round of replication after TG treatment (Fig. 7A, group IV). This would suggest that $\mathrm{TG}$ is incorporated into DNA in a normal fashion, but the TG-containing template causes the subsequent synthesis of damaged DNA leading to the appearance of unilateral chromatid damage. Other investigators $[7.13]$. in contrast, have reported the presence of DNA strand breaks occurring early after $\mathrm{TG}$ treatment. suggesting that the damage could occur in the parental strand at high drug doses. It is possible that this discrepancy is due to different drug doses employed in the various studies.

Maybaum and Mandel [12] suggest that chromatin disruption which occurs in TG-treated CHO cells represents a change in chromosome structure or composition. Furthermore, they suggest that the distortion observed may be due to either breaks in the DNA occurring in the affected region or the failure of the chromatin to condense properly [12]. The data presented here support the former hypothesis. DNA strand breaks, as measured by alkaline elution methods, were observed only when $\left[{ }^{3} \mathrm{H}\right] \mathrm{TdR}$ was incubated for $12 \mathrm{hr}$ with cells that had been pretreated with TG. Coincubation of TG and $\left[{ }^{3} \mathrm{H} \mid \mathrm{TdR}\right.$ during the initial 12-hr period produced no discernible DNA strand breaks. These data suggest that TG incorporation into DNA alone does not produce measurable strand breaks. It is only when $\left[{ }^{3} \mathrm{H}\right] \mathrm{TdR}$ labeling occurs of cells whose DNA is already substituted with TG that the strand breaks are apparent. Other investigators have found DNA strand breaks in TG-treated cells but did not report the time schedule dependence for effects of drug and TdR labeling schedules in their studies [7]. The appearance of DNA strand breakage and unilateral chromatid damage during the same time sequence suggests that these two manifestations of TG-induced damage may play a critical role in TG lethality. Further work will be required to determine if the correlations among DNA damage, DNA strand breakage and cytotoxicity that we have observed are merely the result of drug treatment or the cause of cell death per s'.

Acknowledgements - This research was supported in part by Grants 5-T-32-CA09223 and CA-36946 from the National Institutes of Health, and a Young Investigator Award from Eli Lilly \& Company (K.A.K.). C.R.F. was a predoctoral graduate student in the Department of Pharmacology. The George Washington University and was supported by Grant 5-T-32-CA09223. 


\section{REFERENCES}

1. J. J. McCormack and D. G. Johns, in Pharmacologic Principles of Cancer (Ed. B. A. Chabner), p. 213. W. B. Saunders. Philadelphia (1982).

2. R. J. McCollister. W. R. Gilbert, D. M. Ashton and J. B. Wyngaarden, J. biol. Chem. 239, 1560 (1964).

3. R. P. Miech, R. E. Parks, Jr.. J. H. Anderson, Jr. and A. C. Sartorelli, Biochem. Pharmac. 16, 2222 (1967).

4. A. R. P. Patterson and D. M. Tidd, in Handbook of Experimental Pharmacology (Eds. A. C. Sartorelli and D. G. Johns), Vol. 38. Part 2, p. 384. Springer. Berlin (1975).

5. J. A. Nelson, J. W. Carpenter, L. M. Rose and D. J. Adamson. Cancer Res. 35. 2872 (1975).

6. G. A. LePage, Cancer Res. 20, 403 (1960).

7. N. T. Christie. S. Drake, R. E. Meyn and J. A. Nelson, Cancer Res. 44, 3665 (1984).

8. C. K. Carrico and A. C. Sartorelli, Cancer Res. 37, 1868 (1977).

9. R. D. Armstrong, M. Lewis and E. C. Cadman, Proc. Am. Ass. Cancer Res. 26, 19 (1985).

10. D. M. Tidd and A. R. P. Patterson, Cancer Res. 34, 738 (1974).

11. L. L. Wotring and J. L. Roti Roti, Cancer Res. 40, $1458(1980)$.

12. J. Maybaum and H. G. Mandel, Cancer Res. 43, 3852 (1983).
13. S. H. Lee and A. C. Sartorelli, Cancer Biochem. Biophys. 5. 189 (1981).

14. S. C. Barranco and R. M. Humphrey. Cancer Res. 31 , 583 (1971).

15. A. P. Rao and P. N. Rao, J. natn. Cancer Inst. 57. 1139 (1976).

16. J. Maybaum and H. G. Mandel, Expl Cell Res. 135 , 465 (1981).

17. M. Y. Chu and G. A. Fischer, Biochem. Pharmac. 17. $753(1968)$.

18. W. N. Hittelman and P. N. Rao, J. cell. Phvsiol. 95 333 (1978)

19. K. W. Kohn, R. A. G. Ewig, L. C. Erickson and L. A. Zwelling, in DNA Repair (Eds. E. C. Friedberg and P. C. Hanawalt), p. 379. Marcel Dekker, New York (1981).

20. P. N. Rao and R. T. Johnson. Nature, Lond. 225, 159 (1970)

21. P. N. Rao, B. Wilson and T. T. Puck, J. cell. Physiol. 91, 131 (1977).

22. W. N. Hittelman and P. N. Rao, Cancer Res. 35. 3027 (1975).

23. B. K. Vig and R. Lewis, Mutation Res. 55, 121 (1978)

24. S. Yosida, M. Yamada, S. Masaki and M. Saneyoshi. Cancer Res. 39, 3955 (1979).

25. H. Beikirch, D. Lentfer and A. Lezins, Hoppe-Seyler's Z. physiol. Chem. 353, 677 (1972). 